\title{
Structure of benthic macroinvertebrate assemblages on a gradient of environmental integrity in Neotropical streams
}

\author{
Estrutura da comunidade de macroinvertebrados bentônicos em um gradiente de \\ integridade ambiental em córregos Neotropicais
}

\author{
Marcia Thais Suriano and Alaide Aparecida Fonseca-Gessner \\ Laboratório de Ecologia de Insetos Aquáticos, Departamento de Hidrobiologia, \\ Universidade Federal de São Carlos - UFSCar, São Carlos, SP, Brazil \\ e-mail: a_suriano@yahoo.com.br; gessner@ufscar.br
}

\begin{abstract}
Aim: This study investigated the taxonomic composition of the benthic macroinvertebrates in streams to evaluate how this fauna reflects the various uses of the soil and to identify which groups of macroinvertebrates might be taken as characterizing each situation under study. Methods: To achieve these objectives, 29 streams were collected and inserted in regions with different conservation using Surber sampler. Analyzes were performed of environmental variables (Principal Components Analysis - PCA) and taxonomic structure of the community (taxon richness, numerical abundance and Multidimensional scaling - MDS). Results: EPT group (orders Ephemeroptera, Plecoptera and Trichoptera) and the Coleoptera exhibited greater numerical abundance and taxon richness in streams located in reference areas. In contrast, dipteran larvae, especially the chironomids, along with immature odonates, were more abundant in streams in areas suffering from a lack of riparian forest. Multidimensional scaling analysis (MDS) revealed an environmental gradient, on which the streams within the Atlantic forest formed a tightly clustered group, as did those in semideciduous forests. However, the latter group occupied an intermediate position between the Atlantic forest streams and those in areas disturbed by human activity. Among these areas there were no specific clusters by monoculture. Conclusions: Among the groups of streams defined by the types of land use in the adjacent areas, the state of integrity was found to decline from Atlantic rainforest, through semi-deciduous forest and then pasture, to the monocultures of eucalypts and sugarcane.
\end{abstract}

Keywords: Atlantic forest, streams, environmental integrity, land use, macroinvertebrates.

Resumo: Objetivo: Este trabalho investigou a composição taxonômica da comunidade de macroinvertebrados bentônicos em córregos para avaliar como essa fauna reflete os diversos usos do solo e identificar quais os grupos de macroinvertebrados que podem ser considerados característicos de cada situação em estudo. Métodos: Para isso foram realizadas coletas em 29 córregos inseridos em regióes com diferentes estados de conservação utilizando amostrador Surber. Foram realizadas análises das variáveis ambientais (Análise de Componentes Principais - PCA) e da estrutura taxonômica da comunidade (riqueza taxonômica, abundância numérica e Escalonamento Multidimensional - MDS). Resultados: Os resultados evidenciaram que as ordens Ephemeroptera, Plecoptera e Trichoptera (grupo EPT) e Coleoptera tiveram abundância numérica e riqueza taxonômica maiores nos córregos situados em áreas de referência. As larvas de Diptera, particularmente representadas por Chironomidae, juntamente com os imaturos de Odonata tiveram suas maiores participaçóes em córregos situados em áreas consideradas impactadas pela ausência da mata ripícola. A análise muldimensional (MDS) indicou um gradiente ambiental, através do qual se observou que os córregos situados na Mata Attântica ficaram mais próximos entre si, bem como os córregos em mata semidecídua, porém, este grupo ocupou uma posição intermediária entre os córregos da Mata Atlântica e aqueles de áreas consideradas impactadas, os quais não formaram agrupamentos específicos por monocultura. Conclusóes: De acordo com os grupos de córregos definidos pelo uso do solo, o estado de integridade decresceu da Mata Atlântica, seguido da floresta semidecídua, pastagem, monocultura de eucalipto e cana de açúcar.

Palavras-chave: Mata Atlântica, córregos, integridade ambiental, usos do solo, macroinvertebrados. 


\section{Introduction}

Aquatic systems in a given area of land acquire unique functions that relate to the characteristics of the drainage basin involved. Those characteristics, in turn, depend on the local geomorphology, climate of the region, type of vegetation and amount of human activity in the zones adjacent to the watercourses (Wetzel and Likens, 1991). The physical heterogeneity of streams, availability of food and the integrity of the ecosystem are the main factors affecting the establishment and maintenance of the biotic communities in these water bodies (Wetzel, 1983). The environmental factors are correlated with each other and determine the composition and taxon richness of the biological community.

Both biological and ecological data are needed for an understanding of the relations among species and between them and their habitat. With the aid of such observations it is possible to determine the degree of sensitivity of organisms in lotic habitats to various types of anthropic disturbance, for the purpose of assessing the state of conservation of the environment under the impact of the different land uses, especially where the integrity of riparian forest is affected.

The benthic fauna is a recognized indicator of environmental quality in aquatic, especially lotic, habitats and information on the structure of this community in reference areas may be used as a standard for comparison in environmental monitoring programs. Benthic invertebrates are outstandingly important in the dynamics of ecological processes in water systems and also have several inbuilt characteristics that make them good biological indicators: abundance and broad distribution in all kinds of aquatic system; limited mobility, which ensures that individuals stay in one place; reasonably long life cycle, allowing the state of these populations to be used in explanations of temporal patterns of change caused by human disturbance; differing levels of tolerance (sensitive and tolerant species) to the various types of pollution; integrators of environmental conditions; easy collection and identification, at least at higher taxonomic levels (Rosenberg and Resh, 1993).

Studies on the benthic community have become standard practice in monitoring programs in European countries (Dolédec et al., 1999, 2006; Bady et al., 2005), the USA (Merritt et al., 2002), Australia (Chessman and Royal, 2004) and New Zealand (Dolédec et al., 2006). In Brazil, studies of the impact of human activity on water systems, involving analysis of the macroinvertebrate community, have been concentrated in the south and southeast of the country (Roque et al., 2000; Ometo et al., 2000; Silveira et al., 2005; Guereschi \& Fonseca-Gessner, 2006; Arias et al., 2007; Bieger et al., 2010).

In the State of São Paulo, natural vegetation is found in the form of isolated pockets, more or less restricted to the designated Conservation Units (Cus) that serve as 'reference areas' (Bailey et al., 2003), inserted in regions dominated by extensive monoculture and pasture. The Cus function as references by preserving local biodiversity and the associated genetic resources, with the minimum of human interference (Brito, 2000).

The aim of this study was to analyze the taxonomic composition of the macroinvertebrate community in low-order streams located in reference areas (mixed tropical rainforest, dense tropical rainforest and semideciduous seasonal forest) and in areas subject to the impact of other types of land use (cattle pasture and extensive monoculture in sugarcane and eucalyptus plantations). The information obtained would be used to assess how this fauna might reflect the different uses of the soil and to identify the groups of macroinvertebrates that could be taken to characterize each situation under study.

\section{Material and Methods}

\subsection{Study area}

The State of São Paulo, situated in southeast Brazil, covers an area of $248,800 \mathrm{~km}^{2}\left(95,700 \mathrm{mi}^{2}\right)$ and has approximately 40 million inhabitants, representing $22 \%$ of the Brazilian population. The Tropic of Capricorn crosses this State, which is thus in a tropical-subtropical region, with a mean annual temperature of $16-18{ }^{\circ} \mathrm{C}$ and mean annual rainfall between 1,000 and $1,400 \mathrm{~mm}$ (Fundação SOS Mata Atlântica; INPE, 1993).

The northwest of São Paulo State is characterized by two mountain chains: Serra da Mantiqueira, covered by mixed tropical rain forest, and Serra do Mar, covered by dense tropical ombrophilous forest (rainforest). In the central region of the state the dominant biome is cerrado (savannah-like scrub forest), and in the northeast the characteristic vegetation is seasonal semideciduous forest (IBGE, 1997).

According to Gusmão (1990), 81\% of São Paulo State was originally covered by natural forest, but this area has dwindled over the centuries since colonization, the forest being replaced by human 
habitation (largely unplanned urbanization), industrial zones, extensive monoculture and pasture. One of the main problems confronting efforts to conserve the remaining native forest in this state is that it is extremely fragmented (Myers et al., 2000). Nowadays, $88.27 \%$ of the original Atlantic Forest has been lost, and only $11.73 \%$ of the original vegetation remains (Ribeiro et al., 2009). The landscape consists of a mosaic of land uses, in which small patches of forest are surrounded by areas dominated by extensive monoculture (mainly sugarcane and eucalyptus plantations) and pasture.

The 29 streams chosen for this study were small (first and second order), 15 being located in Conservation Units (Cus) identified as follows in this paper: Parque Estadual de Campos do Jordão (S1, S2, S3, S4 and S5) - Mixed Tropical Rainforest; Estação Ecológica Caetetus (S6), Parque Estadual Furnas do Bom Jesus (S7 and S8), Parque Estadual Vassununga (S9), Parque Estadual do Morro do Diabo (S10, S11 and S12) - Semideciduous
Seasonal Forest and Parque Estadual Intervales (S13, S14 and S15) - Dense Tropical Rainforest, and 14 in areas devoted to the following agribusinesses: sugarcane cultivation (S16, S17, S18, S19 and S20), pasture (S21, S22, S23, S24 and S25) and eucalyptus plantations (S26, S27, S28 and S29) (Figure 1).

\subsection{Environmental characterization}

Environmental measurements were made at each site to characterize habitat conditions and degrees of human disturbance. In 3 different sections of each site, conductivity, dissolved oxygen and $\mathrm{pH}$ were measured with a multiprobe (Horiba U-10) and the velocity of water current by the float method (Bain \& Stevenson, 1999). For each variable, we used the mean of these measures in the statistical analyses. The substrates were classificated by boulder and cobble $(>256 \mathrm{~mm})$, gravel $(2-255 \mathrm{~mm})$, sand $(0.125-2 \mathrm{~mm})$, and mud $(<0.125 \mathrm{~mm})$ (Ward, 1992) and estimated visually the proportion of the stream bed covered.

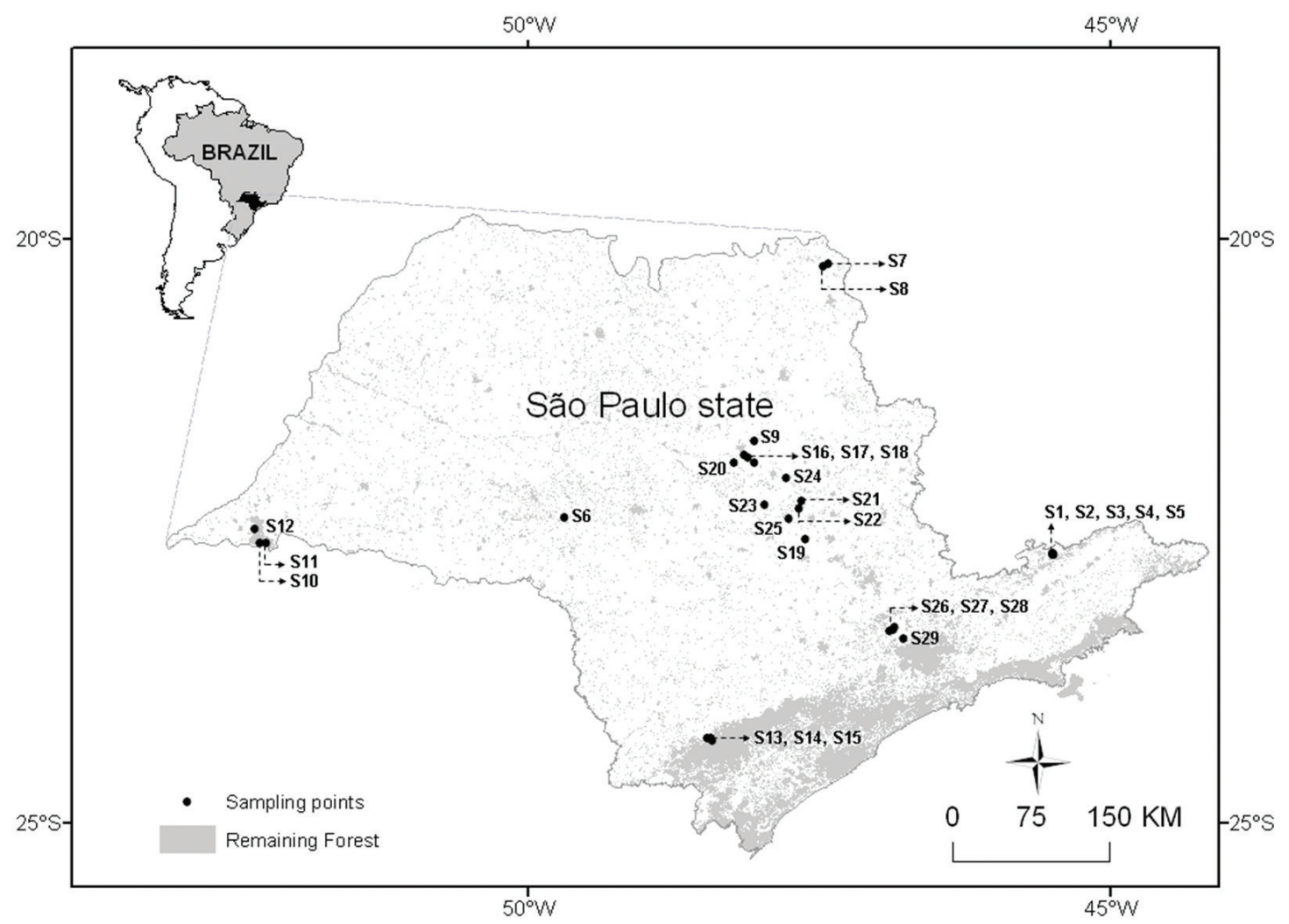

Figure 1. Map of São Paulo State indicating the stream sampling sites: Parque Estadual de Campos de Jordão (S1, S2, S3, S4 and S5), Estação Ecológica Caetetus (S6), Parque Estadual Furnas do Bom Jesus (S7 and S8), Parque Estadual de Vassununga (S9), Parque Estadual Morro do Diabo (S10, S11 and S12), Parque Estadual Intervales (S13, S14 and S15), sugarcane cultivation (S16, S17, S18, S19 and S20); pasture (S21, S22, S23, S24 and S25) and eucalyptus plantations (S26, S27, S28 and S29). 


\subsection{Macroinvertebrate sampling and identification}

A standardized sampling procedure was carried out, with the following criterion: sampled streams were each completely contained in the area of a specific land use. Macroinvertebrates were collected with a Surber sampler $\left(0.1 \mathrm{~m}^{2}\right.$ area and $250 \mu \mathrm{m}$ mesh size) during the dry seasons of 2005 and 2006; six samples were taken randomly along a $100 \mathrm{~m}$ stretch of each stream. Specimens were identified to the lowest practicable taxonomic level, with the help of keys and, when necessary, the advice of specialists (see Acknowledgments).

\section{Data Analysis}

\subsection{Environmental variables}

The values of $\mathrm{pH}$, electric conductivity, dissolved oxygen, average current velocity and stream-bed composition (proportions of boulder, gravel, sand and silt) at each collection site were subjected to principal components analysis (PCA). Our aim here was to extract independent axes expressing the main environmental and human impact gradients. The software used for this analysis was Palaeontological Statistics Software Package - PAST, ver. 1.74 (Hammer et al., 2001).

\subsection{Taxonomic structure of the community}

In the analysis of the data on the fauna, two primary variables were used: the taxon richness (number of taxons found at each sampling site) and numerical abundance (number of individuals in a taxon, in 6 sampling units).

Multidimensional scaling (MDS) analysis is a multivariate ordination method, based on a similarity matrix, that generates a graphical (or spatial) representation of similarity (or distance) between sampling sites. MDS is an exploratory technique that helps the user to visualize the results and displays their possible relationships. Each event is represented by a point in a multidimensional (in the present case 2-D) space and the points are arranged in such a way that the distance between pairs of points shows their degree of similarity. Thus, two similar events are shown as two points a short distance apart (Steyvers, 2001).

In this study, cluster analysis, based on the BrayCurtis similarity index, and MDS analysis were used as exploratory tools to identify the groups of streams with similar macroinvertebrate communities. Analysis of similarity (ANOSIM) was then used to detect significant differences $(p<0.05)$ between these groups of streams and the percent similarity index (PERSIM) was calculated to determine the specific importance of each taxon in each group of streams (Clarke and Warwick, 1994).

Numerical abundance was transformed by the function $\left[\log _{10}(x+1)\right]$, to diminish the influence of dominant and rare taxa. All the analyses mentioned in this section were carried out with the statistical program PRIMER (Plymouth Routines in Multivariate Ecological Research) 6.0 for Windows.

For the final analysis, the streams were also placed in groups according to the type of vegetation in the immediate surroundings: mixed rain forest, dense rain forest, semi-deciduous forest, sugarcane cultivations, pastures and eucalyptus plantation.

\section{Results}

\subsection{Environmental variables}

Among the abiotic variables (Table 1), dissolved oxygen, $\mathrm{pH}$, conductivity, velocity of water current and proportions of boulders, gravel, sand and silt on the stream bed, were incorporated into the PCA. This analysis indicated that the two principal components were able to explain $65.70 \%$ of the variability of the abiotic data. The first principal component (explaining $45.33 \%$ of the total variability) was negatively associated with the variables: boulders, gravel, sand, dissolved oxygen, $\mathrm{pH}$ and current velocity and positively associated with silt and conductivity (Table 2). In general, this component represents a gradient of human impact and land use. There is a clear pattern of separation of the streams located in low-impact areas in the Cus, characterized by high dissolved oxygen content, hard beds of boulder, gravel and sand and fast-flowing water, from those in areas dominated by extensive monoculture or cattle-grazing (which showed silting of the stream bed and higher conductivity) (Figure 2). The second principal component (explaining 20.37\% of the total variability) was positively correlated with the variables: $\mathrm{pH}$, electrical conductivity, current velocity, boulders and silt, and negatively with dissolved oxygen, gravel and sand (Table 2, Figure 2).

\subsection{Taxonomic structure of the community}

\subsubsection{Taxon richness and numerical abundance}

In all, 16,693 benthic macroinvertebrate specimens were collected, showing high taxon richness (number of taxa 192). The insect order Diptera dominated all sampled streams, with a 
Table 1. Geographic data and environmental variables recorded in sampled streams in São Paulo State: map coordinates and altitude (Alt); $\mathrm{pH}$, electrical conductivity (Cond), dissolved oxygen (DO), temperature (T); mean width (Wid); mean depth (Dep); mean velocity (V); percent boulder (B); percent gravel $(\mathrm{G})$; percent sand (Sa); percent silt $(\mathrm{Si}) ;(-)$ not recorded.

\begin{tabular}{|c|c|c|c|c|c|c|c|c|c|c|c|c|c|}
\hline \multirow[t]{2}{*}{ Stream } & \multirow[t]{2}{*}{ Coordinates } & \multirow{2}{*}{$\begin{array}{l}\text { Alt } \\
(\mathrm{m})\end{array}$} & \multirow[t]{2}{*}{$\mathrm{pH}$} & \multirow{2}{*}{$\begin{array}{c}\text { Cond } \\
\left(\mu{\left.\mathrm{S} . \mathrm{cm}^{-1}\right)}^{-}\right.\end{array}$} & \multirow[t]{2}{*}{ DO } & \multirow{2}{*}{$\begin{array}{c}\mathrm{T} \\
\left({ }^{\circ} \mathrm{C}\right) \\
\end{array}$} & \multirow{2}{*}{$\begin{array}{l}\text { Wid } \\
(\mathrm{m}) \\
\end{array}$} & \multirow{2}{*}{$\begin{array}{l}\text { Dep } \\
(\mathrm{m}) \\
\end{array}$} & \multirow{2}{*}{$\frac{V}{(m / s)}$} & \multirow{2}{*}{$\begin{array}{c}\text { B } \\
(\%)\end{array}$} & \multirow{2}{*}{$\begin{array}{c}\mathrm{G} \\
(\%)\end{array}$} & \multirow{2}{*}{$\begin{array}{l}\text { Sa } \\
(\%)\end{array}$} & \multirow{2}{*}{$\frac{\mathrm{Si}}{(\%)}$} \\
\hline & & & & & & & & & & & & & \\
\hline S1 & $22^{\circ} 41^{\prime} 35^{\prime \prime} \mathrm{S} 45^{\circ} 29^{\prime} 23^{\prime \prime} \mathrm{W}$ & 1554 & 6.98 & 11.4 & 8.26 & 15.2 & 1.5 & 0.09 & 0.5 & 5 & 25 & 60 & 10 \\
\hline S2 & $22^{\circ} 41^{\prime} 35^{\prime \prime} \mathrm{S} 45^{\circ} 29^{\prime} 23^{\prime \prime} \mathrm{W}$ & 500 & 6.70 & & 8.46 & 2.8 & 2.0 & 0.08 & & & 40 & 40 & 10 \\
\hline S3 & $22^{\circ} 41^{\prime} 53^{\prime \prime} \mathrm{S} 45^{\circ} 29^{\prime} 02^{\prime \prime} \mathrm{W}$ & 1580 & 6.58 & 6.3 & 8.65 & 14.3 & 1.4 & 0.14 & 0.4 & 5 & 40 & 50 & 5 \\
\hline S4 & $22^{\circ} 41^{\prime} 51^{\prime \prime S} 45^{\circ} 29^{\prime} 20^{\prime \prime} \mathrm{W}$ & 1556 & 6.56 & 1.6 & 8.54 & 13.3 & 1.2 & 0.07 & 0.3 & 10 & 40 & 40 & 10 \\
\hline S5 & $22^{\circ} 41^{\prime} 56^{\prime \prime} \mathrm{S} 45^{\circ} 29^{\prime} 19^{\prime \prime} \mathrm{W}$ & 1555 & 6.56 & & 8.47 & 14.0 & 0.9 & 0.11 & 0.3 & 20 & 40 & 30 & 10 \\
\hline S6 & $22^{\circ} 23^{\prime} 11^{\prime \prime} \mathrm{S} 49^{\circ} 41^{\prime} 10^{\prime \prime} \mathrm{W}$ & 663 & 7.14 & & & 16.7 & 0.6 & 0.10 & 0.1 & 0 & 40 & 50 & 10 \\
\hline S7 & $20^{\circ} 12^{\prime} 07^{\prime \prime}$ & 649 & 8.08 & & 9.85 & 22.7 & 1.2 & 0.09 & 0.3 & 50 & 30 & 10 & 10 \\
\hline S8 & $20^{\circ} 13^{\prime} 46^{\prime \prime S} 47^{\circ} 27^{\prime} 37^{\prime \prime} \mathrm{W}$ & 895 & 7.03 & 3.0 & 7.85 & 21.8 & 0.8 & 0.19 & 0.2 & 50 & 30 & 10 & 10 \\
\hline S9 & $21^{\circ} 43^{\prime} 14^{\prime \prime S} 48^{\circ} 02^{\prime} 53^{\prime \prime} \mathrm{W}$ & 741 & 6.71 & 0 & 10.2 & 20.8 & 1.0 & 0.10 & 0.2 & 0 & 50 & 40 & 10 \\
\hline S10 & $22^{\circ} 36^{\prime} 16^{\prime \prime S} 52^{\circ} 18^{\prime} 02^{\prime \prime} \mathrm{W}$ & 279 & 6.84 & 0.0 & 10.4 & 16.6 & 1.1 & 0.08 & 0.6 & 0 & 80 & 10 & 10 \\
\hline S11 & $22^{\circ} 35^{\prime} 55^{\prime \prime S} 52^{\circ} 14^{\prime} 47^{\prime \prime} \mathrm{W}$ & 234 & 6.32 & 10.0 & 10.3 & 18.4 & 2.3 & 0.05 & 0.3 & 0 & 40 & 50 & 10 \\
\hline S12 & $22^{\circ} 28^{\prime} 34$ & 277 & 6.5 & & 10.2 & 20.5 & 2.5 & 0.16 & 0.3 & 0 & 0 & 90 & 10 \\
\hline S13 & & 850 & & & & & & & & 0 & & & 5 \\
\hline S14 & $24^{\circ} 16^{\prime} 22^{\prime \prime S} 48^{\circ} 27^{\prime} 18^{\prime \prime} \mathrm{W}$ & 840 & 8.40 & 04.0 & 10.0 & 16.7 & 1.2 & 0.28 & 0.4 & 15 & 30 & 55 & 10 \\
\hline S15 & $24^{\circ} 16^{\prime} 20^{\prime \prime} \mathrm{S} 48^{\circ} 25^{\prime} 25^{\prime \prime} \mathrm{W}$ & 840 & 8.70 & 166.0 & 9.60 & 18.1 & 0.8 & 0.20 & 0.6 & 45 & 10 & 40 & 5 \\
\hline S16 & $21^{\circ} 50^{\prime} 56^{\prime \prime} \mathrm{S} 48^{\circ}$ & 678 & 5.30 & 20.0 & 7.0 & 20.0 & - & - & 0.05 & 0 & 0 & 10 & 90 \\
\hline S17 & $21^{\circ} 54^{\prime} 38^{\prime \prime} \mathrm{S} 48^{\circ} 02^{\prime} 53^{\prime \prime} \mathrm{W}$ & 725 & 5.01 & 0.0 & 9.11 & 22.0 & 0.7 & 0.25 & 0.05 & 0 & 0 & 10 & 90 \\
\hline S18 & & 514 & 8.4 & & 6.56 & - & 1.0 & 0.15 & & 0 & 0 & 0 & 100 \\
\hline & $22^{\circ} 33^{\prime} 51^{\prime \prime} \mathrm{S} 47^{\circ} 36^{\prime} 51^{\prime \prime} \mathrm{W}$ & 596 & 5.6 & & & 21.2 & 0.5 & 0.08 & & 0 & 0 & 0 & 100 \\
\hline S20 & $21^{\circ} 52^{\prime} 03^{\prime \prime} \mathrm{S} 48^{\circ} 06^{\prime} 37^{\prime \prime} \mathrm{W}$ & 693 & 5.20 & 80.0 & & 19.5 & - & 0.20 & 0.05 & 0 & 0 & 0 & 100 \\
\hline S21 & $22^{\circ} 18^{\prime} 12^{\prime \prime S} 47^{\circ} 40^{\prime} 14^{\prime \prime} \mathrm{W}$ & 596 & 6.60 & 40.0 & 7.0 & 27.0 & - & 0.50 & 0.07 & 0 & 0 & 20 & 80 \\
\hline S22 & $22^{\circ} 14^{\prime} 19^{\prime \prime S} 47^{\circ} 39^{\prime} 09^{\prime \prime} \mathrm{W}$ & 622 & 7.30 & 210.0 & 6.5 & 25.0 & - & - & 0.07 & 0 & 10 & 10 & 80 \\
\hline S23 & $22^{\circ} 16^{\prime} 28^{\prime \prime S} 47^{\circ} 57^{\prime} 45^{\prime \prime} \mathrm{W}$ & 728 & 5.00 & & 9.2 & 20.0 & - & 0.60 & 0.05 & 0 & 0 & 10 & 90 \\
\hline S24 & $22^{\circ} 02^{\prime} 15^{\prime \prime} \mathrm{S} 47^{\circ} 46^{\prime} 48^{\prime \prime} \mathrm{W}$ & 898 & 6.70 & 20.0 & 8.2 & 25.0 & - & - & 0.07 & 0 & 5 & 0 & 95 \\
\hline S25 & $22^{\circ} 23^{\prime} 26^{\prime \prime} \mathrm{S} 47^{\circ} 45^{\prime} 10^{\prime \prime} \mathrm{W}$ & 572 & 6.50 & 60.0 & 8.0 & - & - & 0.45 & 0.06 & 0 & 0 & 90 & 10 \\
\hline S26 & $23^{\circ} 25^{\prime} 06^{\prime \prime} \mathrm{S} 46^{\circ} 46^{\prime} 26^{\prime \prime} \mathrm{W}$ & 774 & 6.30 & 50.0 & 6.19 & 15.7 & 0.4 & 0.30 & 0.06 & 0 & 0 & 0 & 100 \\
\hline S27 & $23^{\circ} 20^{\prime} 41^{\prime \prime} \mathrm{S} 46^{\circ} 51^{\prime} 44^{\prime \prime} \mathrm{W}$ & 754 & 6.90 & 140.0 & 6.7 & 15.0 & - & - & 0.07 & 0 & 10 & 0 & 90 \\
\hline S28 & $23^{\circ} 19^{\prime} 27^{\prime \prime} \mathrm{S} 46^{\circ} 51^{\prime} 01^{\prime \prime} \mathrm{W}$ & 720 & 8.50 & 100.0 & 6.9 & 16.0 & 0.5 & 0.50 & 0.08 & 0 & 0 & 0 & 100 \\
\hline S29 & $23^{\circ} 21^{\prime} 13^{\prime \prime} \mathrm{S} 46^{\circ} 53^{\prime} 25^{\prime \prime} \mathrm{W}$ & 726 & 7.10 & 29.0 & 7.8 & 15.5 & 0.5 & 0.15 & 0.07 & 0 & 0 & 0 & 100 \\
\hline
\end{tabular}

Table 2. Results of Principal Components Analysis of environmental variable data from 29 small streams in São Paulo State: correlation coefficients of Components 1 and 2 and the variables.

\begin{tabular}{ccc}
\hline $\begin{array}{c}\text { Environmental } \\
\text { variable }\end{array}$ & Component 1 & Component 2 \\
\hline pH & -0.221 & 0.5909 \\
Electrical condutivity & 0.07401 & 0.5911 \\
DO & -0.3743 & -0.2821 \\
Stream velocity & -0.4564 & 0.131 \\
Boulder & -0.2337 & 0.3873 \\
Gravel & -0.415 & -0.08572 \\
Sand & -0.3397 & -0.2123 \\
Silt & 0.505 & 0.04715 \\
\hline
\end{tabular}

total of 7214 specimens representing 12 families, the most abundant being Chironomidae (5969 specimens). The numerical abundance of these fly larvae was highest in streams located in areas disturbed by human activity.

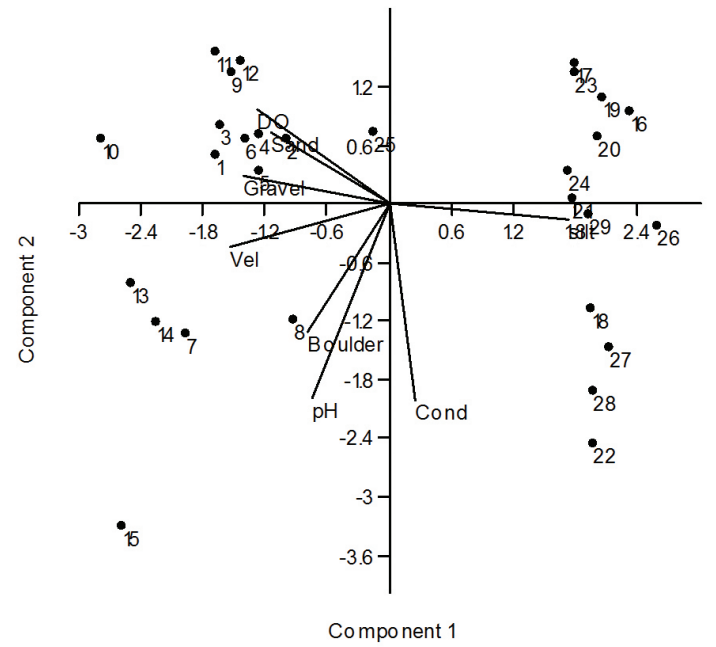

Figure 2. Ordination of 29 streams in São Paulo State generated by applying Principal Component Analysis to environmental variables ( $\mathrm{pH}$, electrical conductivity, DO, stream velocity of water and percent boulder, gravel, sand and silt in the streambed). Components 1 and 2 explain $43.79 \%$ and $26.55 \%$ of the variability respectively. 
Larvae of Ephemeroptera (2605 specimens in 6 families), Plecoptera (513 specimens in 2 families) and Trichoptera (2976 specimens in 14 families) - 'EPT' orders - were especially abundant in streams in reference areas, some genera being recorded only in Cus. On the other hand, some EPT genera, such as Americabaetis (family Baetidae) and Caenis (Caenidae) of Ephemeroptera and Tupiperla (Gripopterygidae) of Plecoptera, were also collected in streams located in disturbed areas, while yet others, such as Oxyethira and Ochrotrichia (Hydroptilidae) of Trichoptera, were found exclusively in these streams. The small order Megaloptera (18 specimens) was recorded in low numbers, particularly in conserved streams.

Coleoptera were also abundant (1466 specimens) and diverse, with examples of 10 families. Elmidae, represented mainly by Heterelmis and Hexacylloepus, was most abundant in the streams located in reference areas.

In the order Odonata (580 specimens), the families Megapodagrionidae, Calopterygidae, Gomphidae, Corduliidae and Aeshnidae were more abundant in streams in reference areas, whereas Coenagrionidae and Libellulidae, represented mainly by the genera Oxyagrion and Brechmorhoga, were found more in human-affected streams, especially where riparian forest had been removed.

Other invertebrates also constituted a significant part of the benthic community: Crustaceans (430 specimens) were abundant in streams in areas of Atlantic Rainforest. Mollusks, represented by 204 gastropods and 138 bivalves, were commonest in streams passing through areas of cattle-grazing or sugarcane monoculture. Hemiptera (117 specimens) and Lepidoptera (26 specimens) were most abundant in streams within Cus, while Platyhelminthes (384 specimens) were found in significant numbers in disturbed streams and the leech group, Hirudinea (22 specimens), was collected in degraded streams.

Numerical abundance was highest in the streams located in reference areas (700 specimens on average, varying from 329 to 2076 individuals), as was taxon richness (52 taxa on average, varying from 30 to 69). The abundance was lower in streams in degraded areas, with 433 specimens on average (varying from 71 to 1057 ) and a mean richness of 32 taxa (range 11-64), the lowest richness occurring in the areas of sugarcane and eucalypt monoculture.

\subsubsection{Multidimensional scaling (MDS) analysis}

The MDS ordination chart (Figure 3) revealed a gradient of environmental quality, on which the streams located in mixed rain forest were grouped close together, as were those located in dense rain forest. The streams in the semi-deciduous forest zone (S6 to S12) also formed a well-defined group, in an intermediate position on the chart, between the Atlantic Rainforest streams and those in areas of anthropic land use. The latter, however, did not form specific groups for each type of land use.

The ANOSIM results showed that significant differences $(p<0.05)$ existed between each pair of groups of streams (Table 3). By means of the percent similarity analysis (PERSIM), it was possible to determine the specific importance of each taxon in the various groups of streams and thus to identify the distinct community structures. The mean percent abundance covered in Log of each taxon in each stream group was calculated and the 20 most numerous taxa are displayed graphically in Figure 4, where it can be seen that there was a rich of taxon compositions in the groups of streams, both in areas of reference (3 types of forest) and in the areas where distinct land uses occur (sugarcane, cattle and eucalypt). Nonetheless, on closer inspection, it is seen that in the 3 forest domains, have most numerical abundance by genera of the EPT group, and in areas to the agribusinesses, by the family Chironomidae, though in the eucalypt plantations 5 genera of the EPT group were also important.

In the streams situated in native forest, a great variety of Trichoptera, Ephemeroptera, Plecoptera

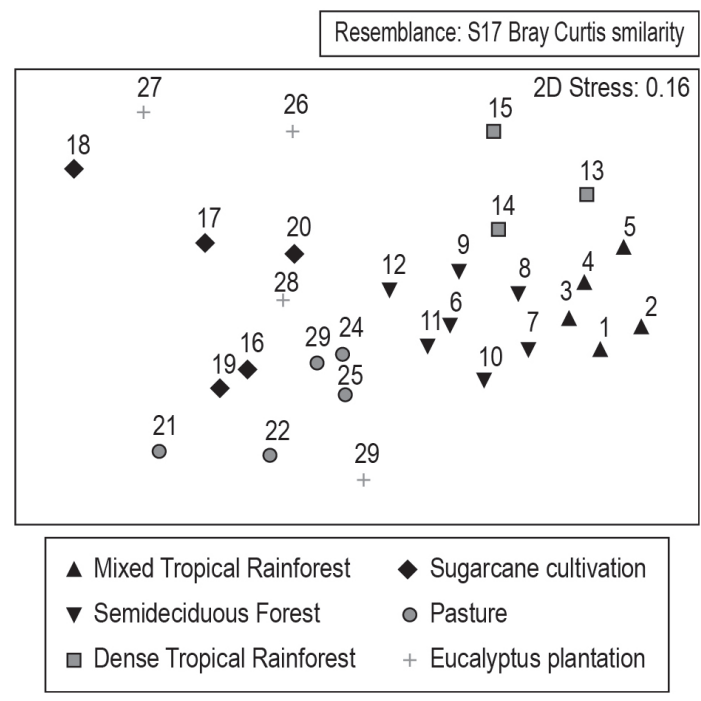

Figure 3. Ordination MDS based on the Bray-Curtis similarity index between of 29 streams in São Paulo State. 
Table 3. Values of analysis ANOSIM ( $p<0,05 \%)$ for the groups of studied streams of low order in São Paulo State.

\begin{tabular}{ccc}
\hline Groups of streams & $\mathbf{R}$ & $\boldsymbol{p}(\%)$ \\
\hline Mixed Tropical Rainforest, Semideciduous Seasonal Forest & 0.738 & 0.1 \\
Mixed Tropical Rainforest, Dense Tropical Rainforest & 0.887 & 1.8 \\
Mixed Tropical Rainforest, Sugarcane cultivation & 0.984 & 0.8 \\
Mixed Tropical Rainforest, Pasture & 1.000 & 0.8 \\
Mixed Tropical Rainforest, Eucalyptus plantation & 0.938 & 0.8 \\
Semideciduous Seasonal Forest, Dense Tropical Rainforest & 0.663 & 0.8 \\
Semideciduous Seasonal Forest, Sugarcane cultivation & 0.845 & 0.1 \\
Semideciduous Seasonal Forest, Pasture & 0.751 & 0.3 \\
Semideciduous Seasonal Forest, Eucalyptus plantation & 0.799 & 1.8 \\
Dense Tropical Rainforest, Sugarcane cultivation & 0.856 & 1.8 \\
Dense Tropical Rainforest, Pasture & 0.990 & 2.9 \\
Dense Tropical Rainforest, Eucalyptus plantation & 0.722 & 1.6 \\
Sugarcane cultivation, Pasture & 0.444 & 2.4 \\
Pugarcane cultivation, Eucalyptus plantation & 0.450 & 0.8 \\
\hline
\end{tabular}
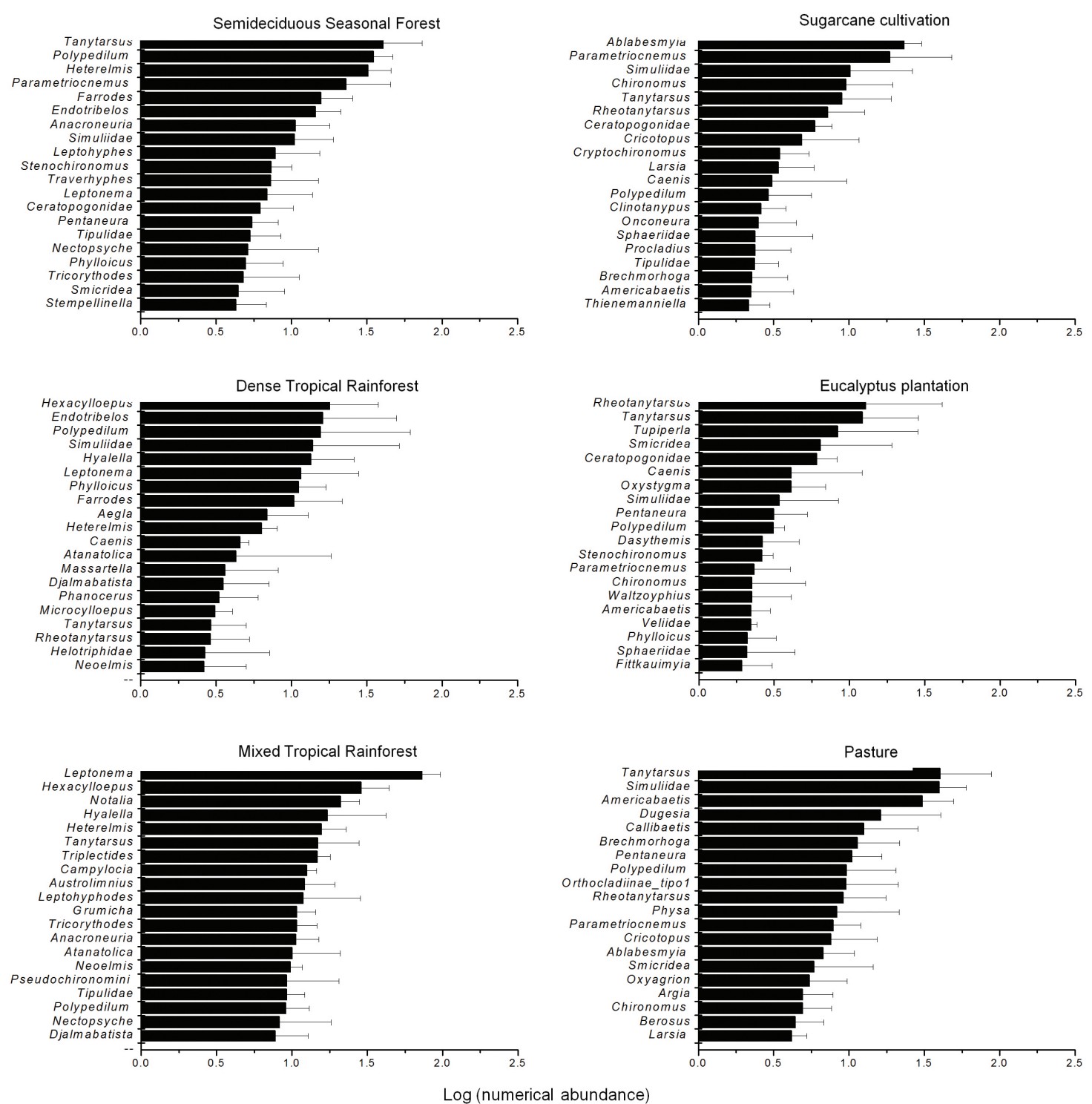

Figure 4. Mean percentages abundance covered in $\log$ and their standard deviations of the twenty most representative taxa in streams of low order in São Paulo State. 
and Coleoptera were observed, as well as some crustaceans. On the other hand, in streams deprived of adjacent natural plant cover, Diptera and Odonata were better represented. Turbellaria and Gastropoda were also prominent in streams running through fields of pasture.

\section{Discussion}

In this study, it was evident from the results of PCA that physical characteristics such as the composition of the stream bed and the current velocity were determining factors in the separation of the streams into two groups: those classified as well conserved and those subject to human interference. The make-up of the stream bed has a strong influence on its colonization by macroinvertebrates and their permanence in a particular habitat (Hynes, 1970; Brown and Brussock, 1991). The conserved streams, with fast-flowing water and beds of large stones, gravel and sand, formed a group that was quite distinct from those in disturbed areas, characterized by slow water, due to the low slope and sinuous contours of the border, whose beds consisted mainly of mud.

The diversity of macroinvertebrates in lotic systems has been related by many authors to the state of the environment, taking into account not only the variety of resources available (Vannote et al., 1980), but also variations in the climate, temperature and stream hydraulics (Statzner and Higler, 1986) and the responses of this community to the many forms of human interference (Allan, 2004; Probst et al., 2005; Burcher and Benfield, 2006; Dolédec et al., 2006).

Streams flanked with riparian forest present more heterogeneous habitats (Hynes, 1970; Vannote et al., 1980) and can give shelter to a more varied fauna (Bojsen and Jacobsen, 2003) than those lacking this vegetation. In this light, riparian vegetation should be recognized as a predictor of a well-balanced taxonomic and functional structure of benthic macroinvertebrates (Feld and Hering, 2007), while its preservation is essential to maintaining the morphology of water bodies, by containing erosion of the banks. The results reported here confirm that streams located in forested reference areas are inhabited by a richer fauna, as they offer a greater variety of habitats for species to colonize (leaves, tree fragments, fruit etc) and food items originating in the riparian zone.

In the areas disturbed by human activity, especially sugarcane plantations and cattle-grazing zones, the total suppression of riparian forest augments the rate at which sand and silt are swept from the banks into the stream, causing the bed to be silted up (Ferreira and Casatti, 2006). This impedes colonization by organisms that depend on a hard substrate, resulting in the exclusion of certain taxonomic groups, including the EPT orders.

From the results of this study, it can be stated that the EPT orders and Coleoptera were characteristic of conserved low-order streams that flowed rapidly over beds consisting mainly of gravel, with an accumulation of leaves reflecting the presence of riverside forest. Similar results have been reported by others (Melo and Froehlich, 2001; Buss et al., 2004; Segura et al., 2007).

The greater richness of Odonata species seen in streams in disturbed areas, particularly in those deprived of adjacent forest, confirms the preference of this order for open areas and its higher tolerance of degraded sites (Buss et al., 2002) and of slow-flowing streams with muddy beds (FerreiraPeruquetti, 2006).

In the Neotropical region, the dipteran family Chironomidae is singled out in many studies for its high taxon richness, reflected in its wide distribution in very diverse habitats (Spies and Reiss, 1996; Suriano and Fonseca-Gessner, 2004). Although some species in this family are classed as sensitive to environmental change, others can tolerate the impact of multiple land use on streams. In fact, the supremacy of chironomids is generally recognized in streams exposed to human interference, such as forest clearance and the influx of inorganic pollutants - including agricultural chemicals leached from fields (Corbi et al., 2010) - also noted in this study.

In this study it was observed that the cattle pasture could be either introduced forage crops or creepers left over from the cleared forest. The expansion of grassy areas on the stream banks in these areas was an important factor that provoked changes in the structure of the fauna established in the new habitats, providing a greater taxonomic richness of fauna in these streams than in those located in sugarcane plantations. Conversely, the eucalypt and sugarcane monocultures caused greater disturbance in the structure and diversity of macroinvertebrate communities, as has been reported by other workers (Bunn, 1988; Canhoto and Graça, 1995). Specific problems are the production of allochthonous matter of much lower nutritional value than that arising from natural forest (Clapcott and Bunn, 2003) and 
contamination by fertilizers and pesticides used on the plantations (Corbi et al., 2010).

Agricultural practices, especially sugarcane monoculture, are responsible for the problems affecting the water bodies in the study area, caused mainly by the clearance of riparian forest to gain land for planting and by the excessive and inappropriate use of agrochemicals. In consequence of these practices, the stream loses its protection and there are increased levels of suspended soil particles, silting of the stream bed and chemical contamination. These changes in the habitat provoke a loss of biodiversity due to the elimination of more sensitive species, favoring the permanence of tolerant species.

The set of factors that includes the absence of riparian forest, raised water temperature, silting up and changes in the benthic macroinvertebrate community could constitute a predictor of stream biotic integrity (Hagen et al., 2006). With its aid, among the groups of streams defined by the types of land use in the adjacent areas, the state of integrity was found to decline from Atlantic rainforest, through semi-deciduous forest and then pasture, to the monocultures of eucalypts and sugarcane.

\section{Acknowledgements}

We express our thanks for help in identifying specimens to Dra. Susana Trivinho Strixino (Chironomidae), Dra. Melissa O. Segura (Coleoptera), Dra. Márcia Spies (Trichoptera), Dra. Ana E. Siegloch (Ephemeroptera), MSc. Lucas Lecci (Plecoptera) and MSc. Luiz Onofre Irineu de Souza, in memoriam (Odonata). Prof. Dr. Marcel O. Tanaka for help statistics analysis. We are also grateful to the BIOTA/FAPESP team for helping us during the development of our project. The São Paulo State Research Foundation sponsored the study within the BIOTA/FAPESP Program - The Biodiversity Virtual Institute Program (www. biotasp.org.br). This work was partly supported by CAPES - Coordenação de Aperfeiçoamento de Pessoal de Nível Superior.

\section{References}

ALLAN, JD. 2004. Landscape and riverscapes: the influence of land use on stream ecosystems. Annual Review of Ecology, Evolution, and Systematics, vol. 35, p. 257-284. http://dx.doi.org/10.1146/annurev. ecolsys.35.120202.110122

ARIAS, ARL., BUSS, DF., ALBURQUERQUE, C., INÁCIO, AF., FREIRE, MM., EGLER, M., MUGNAI, R. and BAPTISTA, DF. 2007. Utilização de bioindicadores na avaliaçáo de impacto e no monitoramento da contaminação de rios e córregos por agrotóxicos. Ciência \& Saúde Coletiva, vol. 12, no. 1, p. 61-72.

BADY, P., DOLÉDEC, S., FESL, C., GAYRAUD, S., BACCHI M. and SCHOLL, F. 2005. Use of invertebrate traits for biomonitoring of European large rivers: the effects of sampling effort on genus richness and functional diversity. Freshwater Biology, vol. 50, p. 159-173. http://dx.doi.org/10.1111/ j.1365-2427.2004.01287.x

BAILEY, RC., NORRIS, RH. and REYNOLDSON, TB. 2003. Bioassessment of freshwater ecosystems using the reference condition approach. Springer. $170 \mathrm{p}$.

BAIN, MB. and STEVENSON, NJ. 1999. Aquatic habitat assessment: common methods. Bethesda: American Fisheries Society.

BIEGER, L., CARVALHO, ABP., STRIEDER, MN; MALTCHIK, L. and STENERT, C. 2010. Are the streams of the Sinos River basin of good water quality? Aquatic macroinvertebrates may answer the question. Brazilian Journal of Biology, vol. 70, no. 4. http:// dx.doi.org/10.1590/S1519-69842010000600010

BOJSEN, BH. and JACOBSEN, D. 2003. Effects of deforestation on macroinvertebrate diversity and assemblage structure in Ecuadorian Amazon streams. Archiv für Hydrobiologie, vol. 158, no. 3, p. 317-342. http://dx.doi.org/10.1127/0003-9136/2003/01580317

BRITO, MCW. 2000. Unidades de Conservação: intençôes e resultados. São Paulo: Annablume, FAPESP. $230 \mathrm{p}$.

BROWN, AV. and BRUSSOCK, PP. 1991. Comparisons of benthic invertebrates between riffles and pools. Hydrobiologia, vol. 220, p. 99-108. http://dx.doi. org/10.1007/BF00006542

BUNN, SE. 1988. Processing of leaf litter in two northern jarrah forest streams, western Austrália: II. The role of macroinvertebrates and the influence of soluble polyphenols and inorganic sediment. Hydrobiologia, vol. 162, p. 211-223. http://dx.doi. org/10.1007/BF00016669

BURCHER, CL. and BENFIELD, EF. 2006. Physical and biological responses of streams to suburbanization of historically agricultural watersheds. Journal of the North American Benthological Society, vol. 25, no. 2, p. 356-369. http://dx.doi.org/10.1899/08873593(2006)25[356:PABROS]2.0.CO;2

BUSS, DF., BAPTISTA, DF., NESSIMIAN, JL. and EGLER, M. 2004. Substrate specificity, environmental degradation and disturbance structuring macroinvertebrate assemblages in neotropical streams. Hydrobiologia, vol. 518, p. 179-188. http://dx.doi.org/10.1023/ B:HYDR.0000025067.66126.1c 
BUSS, DF., BAPTISTA, DF., SILVEIRA, MP., NESSIMIAN, JL. and DORVILLÉ, LFM. 2002. Influence of water chemistry and environmental degradation on macroinvertebrate assemblages in a river basin in south-east Brazil. Hydrobiologia, vol. 481, p. 125-136. http://dx.doi. org/10.1023/A:1021281508709

CANHOTO, C. and GRAÇA, MAS. 1995. Food value of introduced eucalyptus leaves for a Mediterranean Stream detritivore: Tipula lateralis. Freswater Biology, vol. 34, p. 209-215. http://dx.doi. org/10.1111/j.1365-2427.1995.tb00881.x

CHESSMAN, BC. and ROYAL, MJ. 2004. Bioassessment without reference sites: use of environmental filters to predict natural assemblages of river macroinvertebrates. Journal of the North American Benthological Society, vol. 23, p. 599-615. http://dx.doi.org/10.1899/08873593(2004)023<0599:BWRSUO>2.0.CO;2

CLAPCOTT, JE. and BUNN, SE. 2003. Can C4 plants contribute to aquatic food webs of subtropical streams? Freswater Biology, vol. 48, p. 1105-1116. http:// dx.doi.org/10.1046/j.1365-2427.2003.01077.x

CLARKE, KR. and WARWICK, RM. 1994. Change in Marine Communities: An Approach to Statistical Analysis and Interpretation. Plymouth: Plymouth Marine Lab. 144 p.

CORBI, JJ., FROEHLICH, CG., TRIVINHOSTRIXINO, S. and SANTOS, A. 2010. Bioaccumulation of metals in aquatic insects of streams located in areas with sugar cane cultivation. Quimica Nova, vol. 33, p. 644-648. http://dx.doi. org/10.1590/S0100-40422010000300030

DOLÉDEC, S., PHILLIPS, N., SCARSBROOK, M., RILEY, RH. and TOWSEND, CR. 2006. Comparison of structural and functional approaches to determining landuse effects on grassland stream invertebrate communities. Journal of the North American Benthological Society, vol. 25, p. 44-60. http://dx.doi.org/10.1899/08873593(2006)25[44:COSAFA]2.0.CO;2

DOLÉDEC, S., STATZNER, B. and BOURNARD, M. 1999. Species traits for future biomonitoring across ecoregions: patterns along a human-impacted river. Freshwater Biology, vol. 42, p. 737-758. http://dx.doi. org/10.1046/j.1365-2427.1999.00509.x

FELD, CK. and HERING, D. 2007. Community structure or function: effects of environmental stress on benthic macroinvertebrates at different spatial scales. Freshwater Biology, vol. 52, p. 1380-1399. http:// dx.doi.org/10.1111/j.1365-2427.2007.01749.x

FERREIRA, CP. and CASATTI, L. 2006. Influência da estrutura de habitat sobre a ictiofauna de um riacho em micro-bacia de pastagem, São Paulo, Brasil. Revista Brasileira de Zoologia, vol. 23, p. 642-651. http:// dx.doi.org/10.1590/S0101-81752006000300006
FERREIRA-PERUQUETTI, OS. 2006. Preferência por microhabitat dos gêneros de Odonata da Estação Ecológica de Jataí e arredores: ênfase na fase jovem. In SANTOS, JE. Estudos integrados em ecossitemas. Estação Ecológica de Jataí. São Carlos: EdUFSCar. vol. 4, p. 45-60.

Fundação SOS Mata Atlântica and Instituto Nacional de Pesquisas Espaciais - INPE. 1993. Atlas da evolução dos remanescentes florestais da Mata Atlântica e ecossistemas associados no período de 1985-1990. São Paulo.

GUERESCHI, RM. and FONSECA-GESSNER, AA. 2006. Monitoramento da Estação Ecológica de Jataí (Luiz Antônio, SP), utilizando macroinvertebrados bentônicos como indicadores. In SANTOS, JE. Estudos integrados em ecossistemas. Estação Ecológica de Jataí. São Carlos: EdUFSCar. p. 75-98.

GUSMÃO, RP. 1990. Diagnóstico Brasil: ocupação do território e o meio ambiente. Rio de Janeiro. Instituto Brasileiro de Geografia e Estatística.

HAGEN, EM., WEBSTER, JR. and BENFIELD, EF. 2006. Are leaf breakdown rates a useful measure of stream integrity along an agricultural landuse gradient? Journal of the North American Benthological Society, vol. 25, no. 2, p. 330-343. http://dx.doi. org/10.1899/0887-3593(2006)25[330:ALBRAU] 2.0.CO;2

HAMMER, O., HARPER, DAT. and RYAN, PD. 2001. PAST: Palaeontological Statistics Software Package for education and data analysis. Palaeontologia Electronica, vol. 4, no. 1.9 p. Available from: <_TTP://folk.uio.no/ohammer/past>.

HYNES, HBN. 1970. The Ecology of Running Waters. Liverpool University Press. 555 p.

Instituto Brasileiro de Geografia e Estatística - IBGE. 1997. Anuário Estatístico do Brasil. Rio de Janeiro: Ministério do Orçamento e Planejamento.

MELO, AS. and FROEHLICH, CG. 2001. Macroinvertebrates in neotropical streams: richness patterns along a catchment and assemblages structure between 2 seasons. Journal of the North American Benthological Society, vol. 20, p. 1-16. http://dx.doi. org/10.2307/1468184

MERRITT, RW., CUMMIS, KW., BERG, MB., NOVAK, JA., HIGGINS, MJ., WESSELL, KJ. and LESSARD, JL. 2002. Development and application of a macroinvertebrate functional group approach in the bioassessment of remnant river oxbows in southwest Florida. Journal of the North American Benthological Society, vol. 21, p. 290-310. http:// dx.doi.org/10.2307/1468416

MYERS, N., MITTERMEYER, RA., FONSECA, GAB. and KENT, J. 2000. Biodiversity hotspots for conservation priorities. Nature, vol. 403, p. 853-858. http://dx.doi.org/10.1038/35002501 
OMETO, JPHB., MARTINELLI, LA., BALLESTER, MV., GESSNER, A., KRUSCHE, AV., VICTORIA, RL. and WILLIAMS, M. 2000. Effects of land use on water chemistry and macroinvertebrates in two streams of the Piracicaba river basin, south-east Brazil. Freshwater Biology, vol. 44, p. 327-337. http://dx.doi. org/10.1046/j.1365-2427.2000.00557.x

PROBST, M., BERENZEN, N., LENTZENGODDING, A., SCHULZ, R. and LIESS, M. 2005. Linking land use variables and invertebrate taxon richness in small and medium-size agricultural streams on a landscape level. Ecotoxicology and Environmental Safety, vol. 60, p. 140-146. http:// dx.doi.org/10.1016/j.ecoenv.2004.04.003

RIBEIRO, MC., METZGER, JP., MARTENSEN, AC., PONZONI, F. and HIROTA, MM. 2009. Brazilian Atlantic forest: how much is left and how is the remaining forest distributed? Implications for conservation. Biological Conservation, vol. 142, p.1141-1153. http://dx.doi.org/10.1016/j. biocon.2009.02.021

ROQUE, FO., CORBI, JJ. and TRIVINHOSTRIXINO, S. 2000. Consideraçôes sobre o uso de larvas de Chironomidae (Diptera) na avaliação da qualidade da água de córregos do Estado de Sáo Paulo. In ESPÍNDOLA, ELG., PASCHOAL, CMRB., ROCHA, O., BOHRER, MBC. and OLIVEIRA NETO, AL., eds. Ecotoxicologia perspectivas para $o$ século XXI. São Carlos: Rima Editora. p. 115-126.

ROSENBERG, DM. and RESH, VH. 1993. Freshwater biomonitoring and benthic invertebrates. Ney York: Chapman and Hall. 488 p.

SEGURA, MO., FONSECA-GESSNER, AA. and TANAKA, MO. 2007. Composition and distribution of aquatic Coleoptera (Insecta) in low-ordem streams in the state of São Paulo, Brazil. Acta Limnologica Brasiliensia, vol. 19, p. 247-255.

SILVEIRA, MP., BAPTISTA, DF., BUSS, DF., NESSIMIAN, JL. and EGLER, M. 2005. Application of biological measures for stream integrity assessment in south-east Brazil. Environmental Monitoring and Assessment, vol. 101, p. 117-128.

SPIES, M. and REISS, F. 1996. Catalog and bibliography of Neotropical and Mexican Chironomidae (Insecta:Diptera). Spixiana, vol. 22, p. 61-119.

STATZNER, B. and HIGLER, B. 1986. Stream hydraulics as a major determinant of benthic invertebrate zonation patterns. Freswater Biology, vol. 16, p. 127 139. http://dx.doi.org/10.1111/j.1365-2427.1986. tb00954.x

STEYVERS, M. 2001. Multidimensional scaling. Macmillan Reference Ltd. Available from: <http:// forum.gfk.ru/texts/methods/mds.pdf>.

SURIANO, MT. and FONSECA-GESSNER, AA. 2004. Chironomidae (Diptera) larvae in streams of Parque Estadual de Campos do Jordão, São Paulo State, Brazil. Acta Limnologica Brasiliensia, vol. 16, no. 2, p. 129-136.

VANNOTE, RL., MINSHALL, GW., CUMMINS, KW., SEDELL, JR. and CUSHING, C.E. 1980. The River Continuum Concept. Canadian Journal of Fisheries and Aquatic Sciences, vol. 37, p. 130-137. http://dx.doi.org/10.1139/f80-017

WARD, JV. 1992. Aquatic insect ecology: biology and habitat. John Wiley and Sons, Inc. 438 p.

WETZEL, RG. and LIKENS, GE. 1991. Limnological analyses. New York: Springer-Verlag. 391 p. http:// dx.doi.org/10.1007/978-1-4757-4098-1

WETZEL, RG. 1983. Limnology. Philadelphia: Sawders ed. 743 p. 